\title{
Determinant Factors of Consumer Preferences in Indonesia Airlines Industry
}

\author{
ADITYA WARDHANA, SYAHPUTRA, BUDI R. KARTAWINATA \\ Telkom University, Bandung 40257, Indonesia \\ Email correspondence: adityawardhana@telkomuniversity.ac.id
}

\begin{abstract}
This paper is aimed at finding the factors which determine the preferences of consumers in using flight services in Indonesia and knowing the factors of priority preferences of consumers in using the flight in Indonesia. Research methodology used is quantitative method and technical data analysis used is factor analysis. The size of the population of 91 million passengers with a target population of commercial airlines passengers in Indonesia. The total sample by using Slovin formula, with the level of confidence $95 \%$, is 400 respondents. The sample collection technique uses nonprobability sampling with incidental sampling method. Data were collected through questionnaire, observation, and an interview. The results showed that the determinants of consumer's preferences in using flight services in Indonesia can be grouped in three factors arranged based on priority of attributes as follows: (a) tariff consisting of a tariff as attribute, (b) services consisting of attributes such as on-time departure and arrival, safety, reservation and check-in convenience, airline' crews, flight patterns, cabin services, baggage services, and airplanes, and (c) image of airlines composed of airline image as attribute.
\end{abstract}

Key words: airline service, consumer preferences, factor analysis.

\section{Faktor Penentu Referensi Konsumen di Industri Maskapai Penerbanagan Indonesia}

\begin{abstract}
Abstrak
Tulisan ini bertujuan untuk mengetahui faktor-faktor yang menentukan preferensi konsumen dalam menggunakan jasa penerbangan di Indonesia dan mengetahui faktor-faktor preferensi prioritas konsumen dalam menggunakan penerbangan di Indonesia. Metodologi penelitian yang digunakan adalah metode kuantitatif dan data teknis analisis yang digunakan adalah analisis faktor. Ukuran populasi dari 91 juta penumpang dengan populasi target penerbangan penumpang komersial di Indonesia. Total sampel dengan menggunakan rumus Slovin, dengan tingkat kepercayaan 95\%, adalah 400 responden. Teknik pengambilan sampel menggunakan sampel nonprobability dengan metode incidental sampling. Data dikumpulkan melalui kuesioner, observasi, dan wawancara. Hasil penelitian menunjukkan bahwa faktorfaktor penentu preferensi konsumen dalam menggunakan jasa penerbangan di Indonesia dapat dikelompokkan dalam tiga faktor disusun berdasarkan prioritas atribut sebagai berikut: (a) tarif yang terdiri dari tarif sebagai atribut, (b) layanan yang terdiri dari atribut seperti pada waktu keberangkatan dan kedatangan, keselamatan, reservasi dan checkin kenyamanan kru, maskapai, pola penerbangan, layanan kabin, layanan bagasi, dan pesawat terbang, dan (c) citra penerbangan terdiri dari gambar maskapai sebagai atribut.
\end{abstract}

Kata kunci: layanan penerbangan, preferensi konsumen, analisis faktor. 


\section{INTRODUCTION}

The growth of business aviation services for the last decade is quite promising. This is reflected in the increase in the number of air passengers in 2006 reached 3 million people by the end of 2014 had reached 2.4 times or by 91 million people. The size of the market opportunity and the rapid growth of air transport nationally, among others: (a) Indonesia with a population of world's fourth largest about 250 million people, with the percentage of users of aviation services, only about $40 \%$, (b) Indonesia consists of 17,508 islands with the potential mobility of people and the goods and services, (c) Indonesia with a diversity of natural conditions in mountainous areas far from the ocean and are hard to reach with other modes of land, (d) Indonesian Gross Domestic Product (GDP) by $37 \%$ of the total GDP of ASEAN's role in spurring growth, economic area, (e) only $40 \%$, or about 270 domestic routes that have been flown, (f) the industrial growth of aviation services in the range of $10 \%$, (g) 18 airports in conditions over capacity / crowded and 19 airports in the state not yet fully operational 24 hours, and (h) implementation of the ASEAN Open Sky 2015 (free market competition in the aviation sector) where the government sets up five airports, namely Jakarta, Bali, Surabaya, Makassar and Medan (Rudyto, 2015). International Aviation Association (International Air Transport Association / IATA) predicts the magnitude of potential aviation industry will make Indonesia as one of the largest markets in the world (Tyler, 2015).

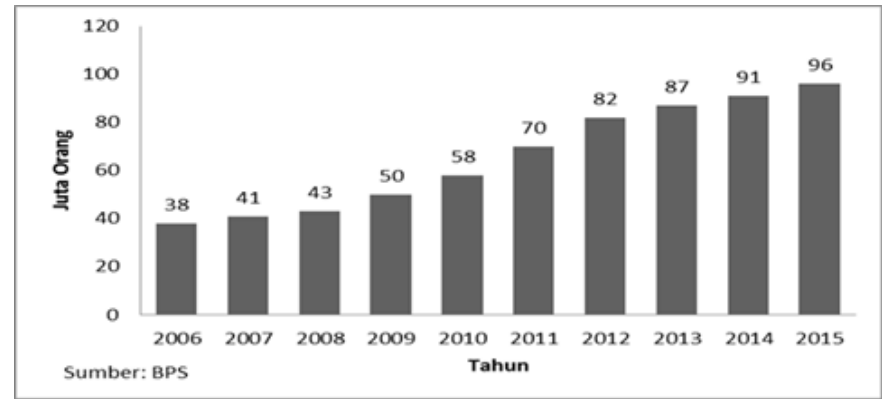

Figure 1. Number of Indonesia Air Transport Passengers

Facing the competitive conditions of business aviation services intensifies, each airline will use a variety of strategies in order to stay in business national airlines such as providing security and flight safety, provide the best service to its customers, providing competitive rates, giving service flights diverse, and so forth.

During the years 2006-2014 1678 aviation accident occurred in ASEAN. Low accident rate in Indonesia is the highest in ASEAN during the years 2006-2014 in the amount of 818 accidents, 525 accidents in Thailand, the Philippines amounted to 143 accidents, Malaysia amounted to 106 accidents, 50 accidents in Laos, Cambodia amounted to 18 accidents, 2 accidents in Vietnam, Singapore amounted to 7 accidents, Myanmar amounted to 3 accidents, and Brunei is 1 accident (Rudyto, 2015).

Regulation of the Minister of Transportation No. 25 of 2008 and Decree No. 9 year 2012 has been arranging a minimum service standards, administrative sanctions, and all violations in the field of aviation. Article 146 of Law No. 1 Year 2009 on Aviation states that the carrier (airline) should be responsible to the loss caused by delay in the transportation of passengers, baggage or cargo. Regulation of the Minister of Transportation No. 77 of 2011 states that if the delay is more than four hours the airline must pay compensation amounting to Rp. 300,000 and if there is a violation, the airline had to divert passengers on other flights without paying additional fees and or provide consumption or accommodation and transport costs if there is no other flight to the destination (Kurniasih, 2015). Airlines operating in Indonesia until 2015 can be explained in the following table.

Table 1. Airlines in Indonesia

\begin{tabular}{cll}
\hline No. & Name of Airlines & \\
\hline 1. & Air Asia & AirAsia is Malaysian Airline \\
2. & Batik Air & Batik Air is the airline of Lion Air Group. \\
3. & Citilink & Citilink is a subsidiary of Garuda Indonesia. \\
4. & Garuda Indonesia & Garuda Indonesia is Indonesia's largest airline. \\
5. & Kal Star Aviation & Kal Star Aviation is a private airline \\
6. & Lion Air & Lion Air is Indonesia's largest private airline \\
7. & Malindo Air & Malindo Air is one of the Indonesian airline. \\
8. Sriwijaya Air & Sriwijaya Air is the airline of Indonesia. \\
9. & Tiger Airways & Tiger Airways is the airline of Singapore. \\
10. & Trigana Air & Trigana air service is the airline of Indonesia. \\
11. & Wings Air & Wings Air is a subsidiary of Lion Air \\
12. Merpati & Merpati Nusantara Airlines is an Indonesian \\
13. Sky Aviation & Sky Aviation is the airline of Indonesia. \\
14. Susi Air & Susi Air is a Indonesian Airline \\
\hline
\end{tabular}




\section{JURNAL BISNIS \& MANAJEMEN}

ISSN 1412 - 3681

Continue of Table 1. Airlines in Indonesia

\begin{tabular}{cll}
\hline No. & Name of Airlines & \multicolumn{1}{c}{ Description } \\
\hline 15 & $\begin{array}{l}\text { TransNusa Air } \\
\text { Services }\end{array}$ & $\begin{array}{l}\text { TransNusa Air Services is the airline of } \\
\text { Indonesia. }\end{array}$ \\
16 & Xpress Air & Air Xpress is an Indonesian airline \\
17 & Nam Air & Nam Air operates under Sriwijaya Air \\
\hline
\end{tabular}

Source: https://www.tiket2.com/airlines, accessed on 12th

September 2015

Based on preliminary research of the fifty respondents who use the services of the airline in the eighteenth and the airline that there are ten attributes or ten factors that form a preference or choice of consumer services of the airline are: safety, tariffs, baggage service, cabin services, condition of the aircraft, airline image, reservation and check-in convenience, ontime departure and arrival, crew, and flight patterns.

The obstacles faced by consumers related to consumer preference service airline, are: aviation security is still lacking as cell phone use by passengers during flight that could interfere with the signal low, the persistence of the airline at a cheap rate, but lack of service, is the length of the handling of passenger baggage, they still lack cabin service during the flight, condition of the aircraft were not convincing passengers, the lack of information regarding the service reservation and check-in for at the airport or online reservation, still frequent delay departures or delays in the arrival at the airport, the crew were less responsive, the flight route which is still limited, and so forth.

Based on the description above, the formulation of the problem in this research is the determinants or factors that shape consumer preferences in choosing the services of airlines in Indonesia. The purpose of this study is to investigate and assess the determinants or factors that shape consumer preferences in choosing the services of airlines in Indonesia.

\section{LITERATURE REVIEW}

Simamora (2004) stated that consumer preference is an act of the consumer in selecting an item in accordance with the level of need. Preferences can be formed through the mindset of consumers is based on several reasons, among others: (a) the experience gained where consumers feel satisfaction in buying the product and felt good in consuming the products, then the consumer will continue to use the product, (b ) of inherited due to the habit of using the product from one generation to another generation, always loyal to the product because of the benefits in the use of products, so that consumers derive satisfaction and benefits of the product. Hawkins \& Mothersbaugh (2010) stated that consumer preference is the knowledge, attitudes, and values that cause consumers to evaluate products, brands and outlet retailers. Consumer makes further decisions generally involve a variety of brands, a variety of attributes, and a number of resources. Moreover, Kevin Lancaster in Nugroho (2008) stated that the approach based on attributes that are considered consumer is not a physical product, but the attributes contained in the product. Attributes are the characteristics possessed by a product that will be selected by the consumer. Consumers usually determine the choice of a product on the qualities of the product itself. According to Indonesian Language Dictionary (2009), the preference is a choice, preferences, trends or things that take precedence, priority, and precedence of the others. So the consumer preference is the tendency of a person to choose the use of certain goods to be felt and enjoyed. In the end consumers are satisfaction of use of the product and loyal to certain brands than similar products.

Finally, based on the definition of consumer preferences above can be formulated that consumer preference is an act of consumers to choose the use of the product, brand and outlet particular retailer based on knowledge, experience, attitudes, and values its possession that involve a variety of brands, a variety of attributes, and a number of resources.

Gilberta \& Wong (2003) stated that the reliability, assurance, facilities, employees, flight patterns, customization, and responsiveness are the dimensions desired by the customer and the airline. Sullivan and Coughlan (2004) stated that the factors which determine consumer's decision to use the transport services and the airline that airline crews, baggage handlers, airplanes, and docking gates. According to David Wessels in Isfahani, Ciptomulyono, \& Ratnasari (2006) defined the variables in air transport services is the price (price), safety (safety), scheduling convenience (schedule appropriate), non-stop flights (direct flights), reservation convenience (ease of booking), baggage handling (baggage handling), on 
time arrival (timeliness of arrival), connecting flights convenience (ease of connecting flights), customer service (service), check-in convenience (ease of checkin). Meanwhile, Clemes, Gan, Kao, \& Choong (2008) stated that the factors which determine consumer satisfaction travel international flights is timeliness, assurance, convenience, helpfulness, comfort, meals, and safety and security. Cento (2009) stated that the key factors that must be provided by the airline that the security, safety and environment. Moreover, Heracleous, and Wirtz (2009) stated that airlines are superior and sustainable implement dual strategy, namely differentiation through service excellence and innovation, together with simultaneous cost leadership in its peer group.

Furthermore, Yulianto (2010) suggested four factors that consumers expect is the complete facilities from authorized agents, the need for explanation passengers fly eligibility conditions, information about the time of check-in, get a guarantee for the seat who has been booking. Furthermore, consumer satisfaction and consumer willingness to recommend the airline very dependent on the efficiency of the service. Companies can create a positive image through the flight information and it will be a way to other company information services. Although, Prakoso et.al (2010) showed that the dimensions of service quality (ServQual) consisting of direct evidence (tangible), reliability (reliability), responsiveness (responsiveness), and a guarantee (assurance) significantly influence consumers consideration in choose air transport services on the route Jakarta Surabaya. Meanwhile, empathy (empathy) does not affect the consumer considerations in choosing air transport services on the route Jakarta - Surabaya. Santorizki (2010) stated that in principle there are several fungus products air freight services that must be achieved: carrying out aviation security (safety), carry out flight orderly and regularly, carry convenient flight (comfortable), and implement economical flight.

Champbell \& Ellis (2011) stated that the safety, punctual / reliable and low price flights of determining consumer choice in using the services of the airline. Hidayat \& Saptarini (2011) stated that the elections were determined by the best airlines factors i.e prices, the number of flights, the accuracy of the flight schedule, aircraft type, the ease of obtaining a ticket, service at airports and ticket changes. Munusamy and Pandian (2011) stated that the price offered, pre-flight services, customer relationship management, cabin environment and in-flight services have an influence on consumer satisfaction.

Shahin and Nekuie (2011) stated that the factors that determine the choice of travel agency and the airline that the external appearance of the building, modern tools and equipment, the appearance of the personnel, appropriate equipment used to deliver service, delivering service at the designated time, willingness to solve customers' problems, delivering on-time and just-in-time service, delivering service exactly at the promised time, accuracy of recording customers' information, informing customers quickly intervening, quick service delivery, willingness to help customers, enough time to respond to customers, good behavior of personnel, safety and security of agency and services, courtesy and good speaking of the personnel, enough knowledge of the personnel, individual attention to customers, appropriate time table for service delivery, delivering specialized service to customers, friendliness of service delivery personnel, and understanding special needs of customers.

Yeoh and Chan (2011) states that the three main attributes that determine domestic customers on low-cost airline in Malaysia i.e on-time departure and arrival, cleanliness of cabin and washroom and a comfortable seat during the whole journey.

Purnama and Raditya (2011) stated that the factors which determine consumer's decision to use the transportation service airline Eva Air is ticket prices are in accordance with the service, prices that are competitive with airline competitors, ease of payment systems, many travel agents are authorized to Eva Air, the ease in obtaining tickets for Eva Air, e-booking convenient, advertising in print media is interesting, in cooperation with travel agents provide a package of interesting, attractive brochure, procedures ticket purchasing easy, capable human resources, ease of information through call center or reservation staff, concierge Eva air is fast and responsive in the face of problems, rapid response in the face of consumer complaints, officers Eva air provide information in a 


\section{JURNAL BISNIS \& MANAJEMEN}

ISSN 1412 - 3681

clear and easily understood, the accuracy of flight departure time, security in case of loss or damage to baggage, the trust of passengers against the clerk, the clerk initiative in assisting passengers, cabin crew were friendly, caring officer against the wishes of passengers, air cleanliness, tidiness officers, and the best facilities.

Archana \& Subha (2012) stated that the quality of services and satisfaction of airline passengers is determined by the dimensions of that in-flight service, digital in-flight service and back-office operations. Provided cuisines, comfort seat safety are the most important dimension in in-flight service quality. Personal entertainment is the most important dimension as perceived by airline passengers in digital In-flight service quality. Online ticket booking is another dimension in back-office operations.

Soomro et.al (2012) stated that the factors which determine consumer preferences in the aviation industry, namely boarding and clearance time, ease of e-ticketing, and luggage capacity. Subagio and Saputra (2012) stated that the quality of service, comfort, and catering will form a corporate image (Image Airline) and perceive value, which then affects customer satisfaction and loyalty Garuda Indonesia in the future.

Salman and Hasim (2012) stated that the strong relationship between government, tourism industry players, local authorities, private agencies and businesses should be fostered to ensure that tourists' needs. Sarker et.al (2012) states that the company must formulate cost differentiation strategy for future growth and sustainability. Ukpere et.al (2012) states that the determinant election airline which sex, age, marital status, income, comfort, on-board services, frequency, crew behavior, fare and power of monopoly. Manivasugen and Nova (2013) states the factors that determine customer preferences budget airlines (low cost carrier) in Indonesia, namely customers, comfort, flight, personnel, airplane type, food, price, baggage, cabin services, punctuality, airline, schedule and safety.

Khuong and Uyen (2014) stated that better employee's services, facilities, image, timeliness, ground services, safety, baggage service, and perceived service quality has a positive relationship with customer satisfaction. Lerrthaitrakul and Panjakajornsak (2014) stated that the low cost carriers, three factors, namely service quality assurance, reliability and empathy have a significant influence on the intensity of post-purchase behavior of consumers. Synder and Tai (2014) stated that the factors that determine customer satisfaction in the airline that is service quality, cost, and customer satisfaction.

Saha and Theingi (2009) stated that there is a relationship between service quality, satisfaction, and behavioral intentions with the three service flights low cost carriers (LCCS) in Thailand by using an attribute that is an additional service fleet, aircraft capacity, and ease of reservation. Nejati et.al (2008) stated that an important attribute is the security of the transport fleet.

The attributes that are considered by the selection (preference) consumers on the airline in this study can be explained in the following table.

Table 2. Attribute Consumer Preferences on Airlines

\begin{tabular}{|c|c|c|}
\hline No. & Attributes & Authors \\
\hline 1. & Safety & $\begin{array}{l}\text { David Wessels in Isfahani, Ciptomulyono, and } \\
\text { Ratnasari (2006), Clemes, Gan, Kao, and Choong } \\
\text { (2008), Nejati, et al (2008), Cento (2009), } \\
\text { Santorizki (2010), Champbell and Ellis (2011), } \\
\text { Shahin and Nekuie (2011), Archana and Subha } \\
\text { (2012), Manivasugen and Nova (2013), Khuong } \\
\text { and Uyen (2014) }\end{array}$ \\
\hline 2. & Tariff & $\begin{array}{l}\text { David Wessels in Isfahani, Ciptomulyono, and } \\
\text { Ratnasari (2006), Santorizki (2010), Hidayat and } \\
\text { Saptarini (2011), Champbell and Ellis (2011), } \\
\text { Munusamy and Pandian (2011), Purnama and } \\
\text { Raditya (2011), Sarker et.al (2012), Manivasugen } \\
\text { and Nova (2013), Synder and Tai (2014) }\end{array}$ \\
\hline
\end{tabular}

3. Baggage Sullivan and Coughlan (2004), David Wessels services dalam Isfahani, Ciptomulyono, and Ratnasari (2006), Purnama and Raditya (2011), Soomro et.al (2012), Manivasugen and Nova (2013), Khuong and Uyen (2014)

4. Cabin services Clemes, Gan, Kao, and Choong (2008), Santorizki (2010), Munusamy and Pandian (2011), Yeoh and Chan (2011), Archana and Subha (2012), Ukpere et.al (2012), Manivasugen and Nova (2013)

5. Airplanes

Sullivan and Coughlan (2004), Yulianto (2010), Prakoso et.al (2010), Hidayat and Saptarini (2011), Purnama and Raditya (2011), Shahin and Nekuie (2011), Manivasugen and Nova (2013)

6. Airline image Yulianto (2010), Kee and Ghazali (2011), Subagio and Saputra (2012), Khuong and Uyen (2014) 
Continue of Table 2. Attribute Consumer Preferences on Airlines

\begin{tabular}{|c|c|c|}
\hline No. & Attributes & Authors \\
\hline 7. & $\begin{array}{l}\text { Reservation } \\
\text { and check-in } \\
\text { convenience }\end{array}$ & $\begin{array}{l}\text { David Wessels in Isfahani, Ciptomulyono, and } \\
\text { Ratnasari (2006), Saha and Theingi (2009), Yulianto } \\
\text { (2010), Hidayat and Saptarini (2011), Munusamy } \\
\text { and Pandian (2011), Purnama and Raditya (2011), } \\
\text { Archana and Subha (2012), }\end{array}$ \\
\hline 8. & $\begin{array}{l}\text { On-time } \\
\text { departure and } \\
\text { arrival }\end{array}$ & $\begin{array}{l}\text { Gilberta and Wong (2003), David Wessels dalam } \\
\text { Isfahani, Ciptomulyono, and Ratnasari (2006), } \\
\text { Clemes, Gan, Kao, and Choong (2008), Prakoso } \\
\text { et.al (2010), Santorizki (2010), Yeoh and Chan } \\
\text { (2011), Purnama and Raditya (2011), Hidayat } \\
\text { and Saptarini (2011), Shahin and Nekuie (2011), } \\
\text { Champbell and Ellis (2011), Soomro et.al (2012), } \\
\text { Manivasugen and Nova (2013), Khuong and Uyen } \\
\text { (2014), Lerrthaitrakul, and Panjakajornsak (2014) }\end{array}$ \\
\hline 9. & Airline crews & $\begin{array}{l}\text { Sullivan and Coughlan (2004), David Wessels dalam } \\
\text { Isfahani, Ciptomulyono, and Ratnasari (2006), } \\
\text { Clemes, Gan, Kao, and Choong (2008), Prakoso } \\
\text { et.al (2010), Shahin and Nekuie (2011), Purnama } \\
\text { and Raditya (2011), Archana and Subha (2012), } \\
\text { Salman and Hasim (2012), Ukpere et.al (2012), } \\
\text { Manivasugen and Nova (2013), Khuong and Uyen } \\
\text { (2014), Lerrthaitrakul, and Panjakajornsak (2014), } \\
\text { Synder and Tai (2014) }\end{array}$ \\
\hline 10. & Flight patterns & $\begin{array}{l}\text { Gilberta and Wong (2003), Hidayat and Saptarin } \\
\text { (2011), Ukpere et.al (2012), Manivasugen and } \\
\text { Nova (2013) }\end{array}$ \\
\hline
\end{tabular}

Source: Adapted from the literature

Finally, based on the above table can be formulated ten attributes or factors into consumer preferences in Indonesia in using airline-safety (safety), tariffs (tariffs), service baggage (baggage services), service cabin (cabin services), condition of the aircraft (airplanes), image carrier (airline image), the comfort of reservation and check-in (reservation and check-in convenience), timeliness depart and arrive (on-time departure and arrival), crew (airline crews), and the pattern or route of flight (flight patterns) as stated in the preliminary study.

\section{RESEARCH METHODS}

In this this study quantitative research method are selected by using descriptive analysis as proposed by Sugiyono (2013) with data analysis techniques using factor analysis as proposed by Simamora (2005). Total population in this study a number of 96 million airline passengers in Indonesia in 2015 based on BPS (Central Bureau of Statistics) data by determining the number of samples in this study using a formula Slovin in order to obtain a sample of 400 respondents. The target population is the respondents who use the services of commercial flights in Indonesia. The sampling technique used in this study is nonprobability sampling method incidental sampling, the method of determination of the sample by coincidence, who are the members of the population by the researchers and willing to become respondents can be sampled, as it considers people who happen to encounter it suitable as a data source (Sugiyono, 2013).

Data were analyzed using factor analysis is a statistical approach that can be used to analyze the interrelationship large number of variables and to describe the dimensions (called factors) whether the underlying variables. The purpose of factor analysis is to condense a large amount of information from a number of original variables into a small number of factors with minimal information loss (Simamora, 2005). Here are the stages in performing data analysis using factor analysis according Simamora (2005):

First determine the purpose of the analysis factors are: (a) the data summarization, and (b) the data reduction.

Second make the design analysis of factors: the number of variables determine the design, measurement techniques, types of variables are allowed, and determine the sample size.

Third perform calculations using a correlation matrix $\mathrm{R}$ factor analysis.

Fourth making assumptions in the analysis of factors. To test the accuracy of the factors that form used statistical tests Barletts Test Sphericity with significant values of $<0.05$ and $\mathrm{KMO}$ to determine the feasibility of factor analysis.

Fifth determine the number of factors (factoring) to determine how much of the variance of the variables. Variances in the variable can be classified into three types of variance, namely: (a) common variance, (b) specific or unique variance, and (c) the error variance. This study using Principal Component Analysis which uses three types of total variance, or the variance. In determining the new factor, which is formed is to look eigenvalue.

Sixth interpret factors. Interpretation of factors conducted in several stages as follows: (a) determining 
the value of MSA through the table KMO and Barlett's Test, (b) determining the number of components that can be maintained by using eigenvalue through tables total variance or by using analysis of the scree plot of the components is obtained, (c) determine or assess the magnitude of the explanation (variance) as well as the unique variance of each variable on the component that is maintained through the table communality, (d) specify the criteria for significant factor loadings, which determines the loading factor worth considering using the criteria of a significant statistic, (e) through analysis table component matrix, can be seen loading and variance of each variable, (f) see the magnitude of the values of communality of each variable to determine the significance of the contribution of each variable to each factor is obtained, and (g) when analyzing the variance (loading) is not satisfactory or not give the desired result, then analyzing would continue using Varimax Rotation (maximizing the value of the variance).

Seventh naming factor (labeling). Once formed groups which are factors of the factor analysis, we then performed the naming process factors or labeling.

\section{RESULTS AND DISCUSSION}

Based on the results of data analysis, the value of MSA results Anti-Image Matrices on the factor analysis are as follows: safety $(0.621)$, tariff $(0.716)$, baggage services (0.312), cabin services (0.323), airplanes (0.271), airline image (0.437), reservation and checkin convenience (.482), on-time departure and arrival (0.689), airline crews (0.356), and the flight patterns (0.344). Based on the results above MSA, then there are ten attributes that can be further analyzed for values greater than 0.5 . To see how many of the factors that will form capable of explaining variables can be seen from the results communalities namely: safety (0.661), tariff (0.782), baggage services (0.328), cabin services $(0.334)$, airplanes (.289), airline image (0.441), reservation and check-in convenience (0.467), on-time departure and arrival (0.771), airline crews (0.362), and the flight patterns $(0,339)$. This study using Principal Component Analysis which use the total variance, generating specific and smallest error variance. In determining the new factor, can be done by looking eigenvalue.
Table 3. Total Variance Explained

\begin{tabular}{|c|c|c|c|c|c|c|}
\hline \multirow{2}{*}{$\begin{array}{c}c \\
o \\
\mathrm{~m} \\
\mathrm{p} \\
\mathrm{o} \\
\mathrm{n} \\
\mathrm{e} \\
\mathrm{n} \\
\mathrm{t}\end{array}$} & \multicolumn{3}{|c|}{ Initial Eigenvalues } & \multicolumn{3}{|c|}{$\begin{array}{l}\text { Extraction Sums of Squared } \\
\text { Loadings }\end{array}$} \\
\hline & Total & $\begin{array}{c}\% \text { of } \\
\text { Variance }\end{array}$ & $\begin{array}{c}\text { Cumulative } \\
\%\end{array}$ & Total & $\begin{array}{c}\% \text { of } \\
\text { Variance }\end{array}$ & $\begin{array}{c}\text { Cumulative } \\
\%\end{array}$ \\
\hline 1 & 1.898 & 27,283 & 27,283 & 1.898 & 27,283 & 27,283 \\
\hline 2 & 1.692 & 21,263 & 48,546 & 1.692 & 21,263 & 48,546 \\
\hline 3 & 1.342 & 19,897 & 68,443 & 1.342 & 19,897 & 68,443 \\
\hline 4 & .775 & 7,541 & 75,984 & & & \\
\hline 5 & .649 & 6,218 & 82,202 & & & \\
\hline 6 & .557 & 5,523 & 87,725 & & & \\
\hline 7 & .512 & 4,672 & 92,397 & & & \\
\hline 8 & .483 & 3,874 & 96,271 & & & \\
\hline 9 & .231 & 2,137 & 96,271 & & & \\
\hline 10 & .163 & 1,592 & 100,000 & & & \\
\hline
\end{tabular}

Source: Data Processing Results

Based on the above table are the ten attributes that added factor analysis. With each attribute has a variant $=1$. Total variant is $10 \times 1=10$. If the 10 attributes are summed up in component or factors formed, then the variance can be explained by each component or factors formed are:

Component 1: 1,898 / $10 \times 100 \%=18.98 \%$

Component 2: $1.692 / 10 \times 100 \%=16.92 \%$

Component 3: $1.342 / 10 \times 100 \%=13.42 \%$

From these calculations, the total of factors could explain $49.32 \%$ of the 10 attributes. From the above table can also be seen there are three components or factors formed, because the component is generated eigenvalue is smaller than 1 are not used in calculating the number of factors formed. After factoring process is done, then proceed with the determination of the loading factor is generated as shown in the following table:

In the table above there are four attributes that the correlation is less than or equal to 0.5 , so it is clear that the factors included into component then no rotation factor. Having sorted the results processing component factor would seem the results as in Table 4 , it appears that the attributes tariff $(0.738)$ is the attribute that most determine consumer preferences in using the services of the airline, followed by the 
attributes of on-time departure and arrival (0.725), then the attributes of safety (0.642), then the attribute reservation and check-in convenience (0.593), then the attribute airline image (0.565), then the attribute airline crews (0.557), then the attribute flight patterns (0.551), then the attribute cabin services (0.543), then the attribute baggage services (0.539), and then attribute airplanes $(0,526)$. From the beginning of the ten factors that included the factor analysis, ultimately formed three factors in the process of naming a factor (factor labeling) in this study is called:

First factors tariffs that consists of attributes tariff. Factors rates become one of the Indonesian consumer preference in using the services of airlines in Indonesia such as the services of low-cost airlines (low cost carrier) and premium class is the choice of consumers in Indonesia

Second factors of service which consists of attributes on-time departure and arrival, safety, reservation and check-in convenience, airline crews, flight patterns, cabin services, baggage services, and airplanes. Factor this service has also become one of the consumer preferences Indonesia in using the services of airlines in Indonesia where the accuracy of the scheduled departure and arrival of aircraft, aviation security, convenience in ticket reservation and check-in, the friendliness of the service given by the cabin crew, flight routes, services for flight, baggage service, and the best physical condition the choice of consumers Indonesia

Third factor of airline image consisting of image airline attributes. Factor these services has also become one of the Indonesian consumer preference in using the services of airlines in Indonesia. Consumers of aviation services in Indonesia makes the airline that has a good image and excel as a preference.

\section{CONCLUSION}

Based on the results of this study concluded that there are ten attributes initial entered factor analysis, ultimately formed three new factors are in the process of naming a factor in this study is called (a) factors tariffs (tariffs) that consists of attributes tariff, (b) a service factor ( services) which consists of attributes on-time departure and arrival, safety, reservation and check-in convenience, airline crews, flight patterns, cabin services, baggage services, and airplanes, and (c) factors image of the airline (airline image) consisting of image airline attributes. These factors become consumer choice preference in using the services of airlines in Indonesia.

\section{REFERENCES}

Archana, R., \& Subha, M.V, (2012). A Study on Service Quality and Passenger Satisfaction On Indian Airlines. International Journal of Multidisciplinary Research 2 (2):50-63

Cento, A, (2009). The Airline Industry: Challenges in the 21st Century. Berlin: Springer.

Champbell, B., \& Ellis, D.V., (2011). The Importance of Choice Attributes and The Positions of The Airlines within The South African Domestic Passenger Airline Industry as Perceived by Passengers at Durban International Airport. Southern African Business Review 16 (2):97119

Clemes, M.D., Gan, C., Kao, T.H., \& Choong, M, (2008). An Empirical Analysis of Customer Satisfaction in International Air Travel. Innovative Marketing 4 (2):49-62

Gilberta, D., \& Wong, R.K.C, (2003). Passenger Expectations and Airline Services: A Hong Kong Based Study. Tourism Management 24:519-532.

Hawkins, D.I., \& Mothersbough, D.L, (2010). Consumer Behavior: Building Marketing Strategy. New York: McGraw Hill.

Heracleous, L., \& Wirtz, J, (2009). Strategy and organization at Singapore Airlines: Achieving Sustainable Advantage Through Dual Strategy. Journal of Air Transport Management 15:274-279. DOI:10.1016/j. jairtraman. 2008.11.011

Hidayat, H.T., \& Saptarini, N.G.A.P, (2011). Sistem Pendukung Keputusan Pemilihan Maskapai Terbaik Pada Rute Domestik Dengan 
JURNAL BISNIS \& MANAJEMEN

ISSN 1412 - 3681

Menggunakan Metode Multi Factor Evaluation Process (MFEP). Jurnal Matrix 4 (3):151-156

Isfahani et.al, (2006). Studi Pelayanan Operasional Penerbangan Pada PT. X Untuk Perumusan Strategi Pengembangan. Prosiding Seminar Nasional Manajemen Teknologi III Program Studi MMT-ITS, Surabaya: A-7,1-8

Khuong, M.N., \& Uyen, L.T.M, (2014). The Factors Affecting Vietnam Airlines Service Quality and Passenger Satisfaction - A Mediation Analysis of Service Quality. International Journal of Innovation, Management and Technology 5 (5):327-333

Kurniasih, Tatit, (2015). Terlambat = Bisnis Terhambat Pangkal Melarat. Service Excellence 02/ V/2015:37-38

Lerrthaitrakul, W., \& Panjakajornsak, V, (2014). The Airline Service Quality Affecting Post Purchase Behavioral Intention: Empirical Evidence from the Low Cost Airline Industry. International Journal of Trade, Economics and Finance 5 (2):155-158

Manivasugen, T., \& Nova, R. (2013). Factors Affecting Customer Preferences While Choosing A Low Cost Airline. Global Journal of Commerce and Management Perspective 2 (3):19-26

Munusamy and Pandian, (2011). Customer Satisfaction Delivery In Airline Industry In Malaysia: A Case of Low Cost Carrier. Australian Journal of Basic and Applied Sciences 5(11):718-723

Nejati et.al, (2008). Ranking Airlines' Service Quality Factors Using A Fuzzy Approach: Study of The Iranian Society. International Journal of Quality \& Reliability Management 26(3):247-260

Nugroho, J.S, (2008). Business Economics and Managerial Decision Making: Aplikasi Teori Ekonomi dan Pengambilan Keputusan
Jurnal Bisnis \& Manajemen, 2017, Vol. XVIII, No. 1, 11-20

Manajerial Dalam Dunia Bisnis. Jakarta: Kencana Prenada Media Group.

Prakoso et.al, (2010). Analisis Pengaruh Dimenso ServQual Terhadap Pemilihan Jasa Transportasi Udara (Maskapai Penerbangan) Rute Jakarta - Surabaya. Wacana 13(3):466474

Purnama, S., \& Raditya, R, (2011). Analisis FaktorFaktor Yang Menentukan Keputusan Konsumen Dalam Pemilihan Penggunaan Jasa Transportasi Udara Pada Maskapai Penerbangan Eva Air. Forum Ilmiah 8(3):184196

Rudyto, Galih, (2015). Membuka Lembaran Baru Bisnis Aviasi Nasional. Aviasi 81(VII):10-12

Sarker et.al, (2012). Sustainability and Growth of Low Cost Airlines: An Industry Analysis in Global Perspective. American Journal of Business and Management 1(3):162-171

Salman, A., dan Hasim, M.S, (2012). Factors and Competitiveness of Malaysia as a Tourist Destination: A Study of Outbound Middle East Tourists. Asian Social Science 8(12):4854

Santorizki, Baskoro, (2010). Struktur Dan Perilaku Industri Maskapai Penerbangan di Indonesia Tahun 2003-2007. Media Ekonomi 18 (3) : $1-23$

Saha, G. C, \& Theingi, (2009). Service Quality, Satisfaction, and Behavioural Intentions: A Study of Low-Cost Airline Carriers in Thailand. Managing Service Quality 19 (3) : 350-372

Shahin, A., \& Nekuie, N, (2011). Development of The Kano Model: A Novel Approach Based On Linear Logarithmic Transformation With A Case Study In An Air Travel Agency. Asian Journal on Quality 12(2):176 - 188

Simamora, Bilson, (2004). Panduan Riset Perilaku Konsumen. Jakarta: Gramedia Pustaka 
Simamora, Bilson, (2005). Analisis Multivariat Pemasaran. Jakarta: Gramedia Pustaka

Soomro et.al, (2012). Factors Effecting Consumer Preferences in Airline Industry. Far East Journal of Psychology and Business 7 (1) : 63-72

Subagio, H., dan Saputra, S, (2012). Pengaruh Perceived Service Quality, Perceived Value, Satisfaction Dan Image Terhadap Customer Loyalty (Studi Kasus Garuda Indonesia). Jurnal Manajemen Pemasaran 7(1):42-51. DOI: 10.9744/pemasaran.7.5.42-52

Sugiyono, (2013). Metode Penelitian Manajemen. Bandung: Alfabeta.

Sullivan, U.Y., \& Coughlan, A.T, (2004). Alliance Structure and Success in the Global Airline Industry: an Empirical Investigation. Online Version: http://www.business.uiuc.edu/ Working_Papers/papers/04-0113.pdf
Synder, D.J., \& Tai, P.A, (2014). Customer Satisfaction at Low Cost Airlines: A Case Study Of Jetstar Pacific Airlines (JPA). Proceeding The Clute Institute International Academic Conference San Antonio: 254-265

Tyler, Tony, (2015). Membangun Potensi Penerbangan Indonesia Versi IATA. Aviasi 81(VII):12

Ukpere et.al, (2012). Determinants of Airline ChoiceMaking: The Nigerian Perspective. African Journal of Business Management 6(15):5442-5455

Yeoh, E., \& Chan, J.K.L, (2011). Malaysian Low Cost Airlines: Key Influencing Factors on Customers' Repeat Purchase Intention. World Applied Sciences Journal 12(Special Issue of Tourism \& Hospitality):35-43

Yulianto, A, (2010). Meningkatkah Kualitas Pelayanan Jasa Penerbangan Indonesia Paska Insiden Kecelakaan Pesawat Terbang?. Jurnal Dinamika Manajemen 1(1):1-8 